\title{
New restaurants and their intra-industry effects: evidence from Portugal
}

O efeito intra-indústria da abertura de novos restaurantes: o caso português

\author{
Luís Miguel Serra Coelho
}

University of Algarve - Faculty of Economics and CEFAGE, Campus de Gambelas, Edifício 9, 8005-139, Faro, Portugal, Icoelho@ualg.pt

\begin{abstract}
This paper investigates the intra-industry effects resulting from the birth of a new restaurant at Portugal. Using event-study methods, this paper finds that, in the year the new competitors open for business, industry rivals experience an average abnormal loss of $-17.6 \%$ in their return-on-assets, which is due to a significant decrease in their profit margin, and asset turnover ratio. Regression analysis further shows that high industry concentration, low labor productivity, and low asset profitability magnify the rivals' underperformance, which is particularly acute when the restaurants are located at Lisbon and Oporto, the two most heavily populated Portuguese cities. Overall, this paper contributes to the literature studying the economics of the eating-places industry, and has important implications for both practice, and public policy.
\end{abstract}

Keywords: Restaurants, intra-industry effects, abnormal operating performance, event-study.

\section{Resumo}

Este artigo investiga os efeitos intra-indústria que resultam da abertura de um novo restaurante em Portugal. Recorrendo ao método do estudo de evento, mostra-se que os restaurantes rivais sofrem uma redução anormal da sua rendibilidade do activo na ordem dos $-17.6 \%$ no ano em que os competidores iniciam a sua actividade, a qual parece resultar de uma queda anormal da sua margem de lucro e rotação do activo. A utilização da análise de regressão permite ainda verificar que uma elevada concentração da indústria, a localização numa grande cidade como Lisboa ou Porto e a existência de baixos níveis de produtividade do factor trabalho são factores que magnificam os resultados anteriormente mencionados. 0 presente artigo contribui assim para melhor se compreender a dinâmica empresarial ligada ao sector da restauração, tendo importantes implicações para a prática e para a definição de políticas públicas.

Palavras-chave: Restauração, efeito intra-indústria, performance anormal, estudo de evento.

\section{Introduction}

Tourism is a significant driver of social development as it stimulates economic growth, generates income, employment, investment and exports. As such, not surprisingly, tourism is one of the most important economic sectors in the World. To this point, a 2013 research brief released by the EU Centre in Singapore reveals that, in 2012 , tourism contributed with a staggering US\$ 6,631 billion to the global Gross Domestic Product (GDP), and was responsible for $8 \%$ of the EU-27 zone GDP. Portugal is a member of the Euro Zone and, like most southern European countries, has a thriving tourism sector. The 2013 EU Centre in Singapore research brief cited above points out that, in 2012, Portugal was the $35^{\text {th }}$ destination in the world, receiving over 10 million international tourists in that year. Statistics Portugal reveals that, in that same year, tourism-related industries accounted for $5.2 \%$ of the country's GDP.

Restaurants are particularly important for Portuguese tourism. In its latest study about this industry, the Central Bank of Portugal reports that, in 2009, the country had around 28 thousand restaurants, which were directly responsible for more than 120 thousand jobs, generating $€ 4$ billion in sales. Yet, there is still very little research on the economics of these firms. This paper starts filling in this gap in the literature by exploring the intra-industry effects resulting from the birth of a new restaurant at Portugal. Using the event-study method proposed by Barber and Lyon (1996), this paper shows that, on average, such event leads industry rivals to experience an abnormal and significant loss of $17.6 \%$ in their return-on-assets in the year the new competing restaurant opens for business. Such underperformance is due to both a decline in the profit margin and in the asset turnover ratio. Interestingly, the event-study results also suggest that this is a short-term effect. In particular, in the following year, industry rivals exhibit an operating performance that is consistent with their level of risk.

In the second part of the paper, regression analysis helps explain the factors behind the rivals' initial underperformance. In particular, there is evidence to suggest that, ceteris paribus, competitors based at Lisbon and Oporto, the two most heavily populated Portuguese cities, are likely to experience a more significant deterioration in their operating performance than similar rival restaurants located elsewhere in the country. Industry concentration, and low employee productivity also magnify the rivals' underperformance. Yet, the birth of a new restaurant is less taxing on pre-existing competitors that display higher profitability levels both in absolute terms, and relative to their city's industry mean.

This paper is of interest for two main reasons. First, although a few studies already investigate how new Small and Medium Enterprises (SMEs) perform when they enter the market (e.g. Lu \& Beamish, 2001; Simpson, Padmore \& Newman, 2012; Mayer-Haug, Read, Brinckmann, Dew \& Grichnik, 2013), there is a dearth of evidence on how their birth affects the operating performance of their respective industry rivals. In fact, the parallel studies investigating somewhat related issues focus on the impact of Initial Public Offerings (IPOs) on their listed competitors (e.g. Akhigbe, Borde \& Whyte, 2003, Braun \& Larrain, 2009; Hsu, Reed \& Rocholl, 2010; Cotei \& Farhat, 2013). Yet, SMEs are very different from publicly listed companies, which justifies revisiting the topic using SME-based samples, a hardly negligible issue since these companies are the backbone of the EU's economy, generating $28 \%$ of its GDP and providing jobs for 88.8 million people in 2013 (European Commission, 2014). Second, this paper sheds light on the economics of the eating-places industry, a largely unexplored topic in the literature. In effect, despite some studies addressing 
issues like the performance, valuation and training of human resources (e.g. Agut, Grau \& Peiró, 2003; Murphy, 2007; Koys \& DeCotiis, 2015), and the prediction of financial distress of restaurants (e.g. Kim \& Upneja, 2014), evidence on this industry's economic dynamics is still scant. Studying the intra-industry effects resulting from the birth of a new restaurant is thus a significant contribution to the academic literature in its own right.

At a different level, this paper's results should be of interest for industry practitioners, and also have relevant public policy implications. In effect, this paper shows that increased competition in the eating-places industry must worry investors and managers working in the sector as, in general, in the short-run, it leads to a significant decrease in the profitability of the existing firms. Regulators learning from this paper's results should consider designing a set of specific rules and regulations in order to ensure that competition in the industry does not question its future economic feasibility.

The balance of the paper is as follows. The next section summarizes the research background, and introduces the paper's research question. Sections 3 present the data, and Section 4 the methodology. Sections 5 summarizes the event-study results, and Section 6 presents the evidence collected through regression analysis. Section 7 concludes.

\section{Research background and research question}

\subsection{Research background}

An intra-industry effect occurs when a firm-specific event affects the valuation and performance of the rival companies working in the same industry, and has been documented in different settings. For instance, in their 1984 seminal study, Foster, Olsen \& Shevlin report a significant intra-industry effect following earnings releases, a topic revisited, among others, by Pyo \& Lustgarten (1990), Asthana \& Mishra (2001), Ramnath (2002), Tookes (2008), and Thomas \& Zhang (2008). Firth (1996), on the other hand, explores the intra-industry effects associated with dividend change announcements, whereas Szewczyk (1992) finds that industry rivals exhibit negative stock abnormal returns once a direct competitor announces it is raising additional equity, or issuing convertible or straight debt. In a similar vein, Gleason, Jenkins \& Johnson (2008) report rivals to experience negative stock abnormal returns following accounting restatements, with Zhang (2010) finding similar evidence in a sample of firms competing in industries that see rivals emerging from Chapter 11 bankruptcy. In contrast, Tawatnuntachai \& D'Mello (2002) find that, on average, rivals earn positive and significant abnormal stock returns when their competitors announce a stock split.

Recent research by Akhigbe, Madura \& Martin (2015) looks at the valuation effects on rivals that result from the sharp decline in the stock price of one of the firms operating in the industry. Their results clearly show that such an event leads to a significant contagion effect, which seems to be particularly severe when the rivals present high default likelihood. Moreover, such intraindustry effect seems to be conditioned by the relative size of the firm experiencing the negative surprise, on how similar the rivals are relative to the firm experiencing the negative surprise, and the degree of concentration of the industry. In a related study, Chang,
Hung \& Tsai (2015) investigates credit risk effects of bond rating downgrades on downgraded firms' intra-industry rivals, suppliers and customers, and show that rivals and suppliers endure very significant increases in their credit spreads as a result of such an event. In another recent contribution, Xin, Peng \& Ying (2015) look at how a potential intra-industry effect is affected by corporate governance. In particular, the authors consider a sample of Chinese companies that face some type of corporate scandal and show that such event leads to a contagion effect in the industry conditional on the quality of corporate governance and degree of political connections. Results also suggest that, in general, good governance in peers' firms reduces contagion; further, ownership concentration and the quality of auditors seem to be particularly important when the contagion effect is due to some form of financial scandal. Xin et al. (2015) also shows that intra-industry effects are different for state and non-state owned firms.

Closer to the present research is the literature exploring the intraindustry effects triggered by IPOs. Akhigbe et al. (2003) are among the first to look into this topic with a sample of 2,493 U.S. IPOs occurring in the 1989-2000 period. Using standard event-study methods, the authors conclude that IPOS are purely firm-specific events since they are unable to lead industry rivals to experience positive or negative stock abnormal returns. Braun \& Larrain (2009), however, dispute Akhigbe et al.'s (2003) main conclusion. In particular, these authors use a sample of 254 IPOs from 22 emerging markets, and find that such events permanently affect the market price of the pre-existing stocks. Braun \& Larrain (2009) show that the intra-industry effect is stronger when the IPO is issued in markets that are less integrated internationally, when the IPO is bigger, and when the stock return of the other assets is highly correlated with that of the firm undertaking the IPO. Hsu et al. (2010) revisit the topic using a sample of 4,188 completed and 1,630 withdrawn U.S. IPOs occurring between 1980 and 2001. Their main conclusion is that rival companies experience negative stock price reactions to completed IPOs in their industry, and positive stock price reactions to their withdrawal. The authors also show that industry rivals exhibit significant deterioration in their operating performance following a successful IPO. In a recent contribution, Cotei \& Farhat (2013) explore whether the financing structure of the IPO affects its intra-industry effects. To do so, the authors collect a sample of 1,681 IPOs, some of which were backed by venture capital. Cotei \& Farhat (2013) find that, in general, IPOs signal positive prospects for the industry, with such information transferred into the stock price of publicly traded rivals. This effect seems to be driven by the ventured backed IPOs, especially when industry concentration is low and when the IPOs yield larger proceeds. Thanh, Ninon \& Dung (2014) provide additional evidence on this issue. In particular, this paper examines whether firms repurchase their stock as a reaction to the competitive threat posed by strong IPO activity within their industry. Using a sample of 35,445 firm-year observations of 5,678 firms that span from 1988 to 2011, Thanh et al. (2014) uncover evidence that suggests that industry rivals employ stock repurchases schemes to correct for the market's overreaction to the IPO threat. In addition, results suggest that IPO-induced repurchases tend to occur in more concentrated industries, and when the rival firm experiences poor stock performance in the previous year. 


\subsection{Research question}

As the previous paragraphs suggest, the extant research already provides evidence on a myriad of intra-industry effects that are triggered by many different events. Yet, all the studies cited above share a common characteristic: they only consider publicly listed firms. To this point, a wider and much more extensive search conducted on databases such as EBSCO Host Research, Proquest, and SSRN confirms that no previous study has explored the issue of intra-industry effects as they apply to non-listed firms.

One possible way to start shedding some light on this very important but largely disregarded topic is exploring how rivals react to the birth of a new competitor, with the eating-places industry providing an interesting setting for exploring such a question. In fact, restaurants are easy to identify, and their business is relatively simple to understand. In addition, restaurants provide a proximity service, which is helpful when one needs to define what an industry rival is. Furthermore, ex-ante, it is not possible to know how a new restaurant affects the performance of its pre-existing competitors as three possibilities can be entertained. For instance, if demand for eating-places in the area is finite, then the birth of a new competitor is likely to divert costumers from the pre-existing restaurants. This would translate into lower sales, and crushed profit margins, which would be harmful for the profitability of the pre-existing businesses. Yet, the birth of a new restaurant may actually increase demand for eatingplaces in the area. This may be the case if the new restaurant adds to the existing supply by providing a different type of cuisine or service, if it eases the overall queuing time that one faces to be served, or if it simply helps to build a positive reputation for the area among costumers. Finally, the pre-existing restaurants may be unaffected by the birth of a new competitor. This could be the case if these businesses have a strong customer base and/or provide a much-differentiated service, if demand in the area is simply too high or if the new restaurant is unable to appeal to costumers for some reason. So, how does birth of a new restaurant actually affect its industry rivals? This is the main research question addressed in this paper.

\section{Data and summary statistics}

The data used for this study comes from the AMADEUS database of Bureau Van Dijk, which contains the financial statements of 21 million listed and privately held firms in Europe. This paper starts with 657 privately held restaurants (i.e. with SIC code equal to 5812) that were incorporated in one of Portugal's 308 municipalities in 2012 as either a "Sociedade Unipessoal por Quotas", a "Sociedade por Quotas" or a "Sociedade Anónima". Furthermore, these firms are all SMES (European Union Recommendation 2003/361), reporting nonconsolidated financial statements at the end of their incorporation year. The focus of this paper is on firms incorporated in 2012 for two reasons. First, the EU Commission Regulation 1725/2003 requires Portuguese firms to report their financial statements according to the International Financial Reporting Standards after 2009 (see Diário da República, 1. a série - N.o $133-13$ de Julho de 2009 for more details). As such, for comparability reasons, this paper cannot use pre-2010 accounting data. Second, the accounting data available at AMADEUS currently ends in 2013. Given that this paper's methodology requires two years of pre-event data and one year of post-event data, 2012 is the only year one can consider to identify the new restaurants in the sample.

This paper next looks for suitable industry rivals. For each new restaurant, a rival is a firm with SIC code equal to 5812 in 2012, and that has its fiscal address on the same seven-digit Zip-Code. Industry rivals are retained if they: 1) are a privately held Portuguese SME, reporting nonconsolidated financial statements at the calendar year-end; 2) have enough accounting data on AMADEUS to conduct the analysis; 3) are not incorporated in 2012. This step eliminates 261 new restaurants from the initial list. In the final step, this paper looks for benchmark firms for the rivals, which is a methodological requirement. In particular, as detailed in Section 4. below, benchmark firms are matched on size and return-on-assets. All industry rivals for which a valid benchmark firm cannot be found are deleted. In the end, this paper's data is comprised of 108 new restaurants, which correspond to 157 different rivals. The mean number of industry rivals per new restaurant is 1.5 (standard deviation is 0.9 ), and the corresponding median is 1.0. The maximum (minimum) number of industry rivals per new restaurant is $6(1)$.

Table 1 presents the main characteristics of the new restaurants, and their rivals in 2012.

Table 1 - Characteristics of the new restaurants and their industry rivals

\begin{tabular}{|c|c|c|c|c|}
\hline & \multicolumn{2}{|c|}{ New Restaurants } & \multicolumn{2}{|c|}{ Ind. Rivals } \\
\hline & Frequency & $\%$ & Frequency & $\%$ \\
\hline \multicolumn{5}{|l|}{$\begin{array}{l}\text { Panel A - Firms were } \\
\text { incorporated as: }\end{array}$} \\
\hline $\begin{array}{l}\text { "Sociedade Unipessoal por } \\
\text { Quotas" }\end{array}$ & 35 & 32.4 & 11 & 7 \\
\hline "Sociedade por Quotas" & 71 & 65.7 & 144 & 91. \\
\hline "Sociedade Anónima" & 2 & 1.9 & 2 & 1 \\
\hline Total & 108 & 100 & 157 & 10 \\
\hline \multicolumn{5}{|l|}{$\begin{array}{l}\text { Panel B - Firms were } \\
\text { incorporated at: }\end{array}$} \\
\hline Lisbon & 28 & 25.9 & 39 & 24 \\
\hline Oporto & 8 & 7.4 & 9 & 5. \\
\hline Other Muncipalities & 72 & 66.7 & 109 & 69 \\
\hline Total & 108 & 100 & 157 & 10 \\
\hline \multicolumn{4}{|l|}{$\begin{array}{l}\text { Panel C - Firm size in } 2012 \text { (EU } \\
\text { 2003/361) }\end{array}$} & \\
\hline Micro & 95 & 88.0 & 113 & 72 \\
\hline Small & 13 & 12.0 & 42 & 26. \\
\hline Medium-sized & 0 & 0.0 & 2 & 1. \\
\hline Total & 108 & 100 & 157 & 1 \\
\hline
\end{tabular}

As can be seen on Panel A of Table 1, most of the new restaurants and respective industry rivals are a "Sociedade por Quotas" (65.7\%, and $91.7 \%$, respectively). Furthermore, Panel B of the same Table shows that one in every three new restaurants are incorporated at Lisbon or Oporto. Not surprisingly, the same applies to their industry rivals. Panel $\mathrm{C}$ of Table 1 shows that the vast majority of the firms in the sample are micro firms. In particular, 95 new restaurants (or $88.0 \%$ of the total) fall within such a category; 113 industry rivals (or $72.0 \%$ of the total) are 
likewise micro firms. Importantly, there are almost no mediumsized firms in the sample: the percentage of new restaurants in such a category is zero, and is $1.3 \%$ for the rivals. Table 2 presents summary statistics for the new restaurants, and their industry rivals. Data is collected at the 2012 year-end, and all variables are winsorized at the first and the $99^{\text {th }}$ percentiles to remove the influence of extreme outliers.

Table 2 - Summary statics for the new restaurants and their industry rivals

\begin{tabular}{|c|c|c|c|c|c|c|}
\hline \multirow{2}{*}{ Variable } & \multicolumn{2}{|c|}{ New Restaurants } & \multicolumn{2}{|c|}{ Ind. Rivals } & \multicolumn{2}{|c|}{ Diff. (New Rest. - Ind. Rivals) } \\
\hline & Mean & Median & Mean & Median & Mean & Median \\
\hline TA & $75,128.6$ & $30,091.0$ & $244,536.8$ & $105,500.0$ & $-169,408.2^{* * *}$ & $-75,409.0 * * *$ \\
\hline SALES & $81,777.2$ & $34,912.5$ & $308,279.7$ & $150,117.0$ & $-226,502.5^{* * *}$ & $-115,204.5^{* * *}$ \\
\hline $\mathrm{CF}$ & $-13,257.1$ & $-11,093.5$ & $-1,502.6$ & $-7,469.5$ & $-11,754.0^{* *}$ & $-3,624.0^{* *}$ \\
\hline SHER & $-46.8 \%$ & $-16.6 \%$ & $-61.7 \%$ & $8.5 \%$ & $14.9 \%$ & $-25.2 \% * *$ \\
\hline ROA & $-76.8 \%$ & $-35.4 \%$ & $-34.2 \%$ & $-12.2 \%$ & $-42.6 \% * * *$ & $-23.2 \% * * *$ \\
\hline $\begin{array}{l}\text { Notes: } \\
\text { 1. TA: Total } \\
\text { 2. SALES: To } \\
\text { 3. CF: Cash- } \\
\text { 4. SHER: Sha } \\
\text { 5. ROA: Ret } \\
\text { 6. *** signif } \\
\text { (Wilcoxon-Ma }\end{array}$ & $\begin{array}{l}\text { s (in euros). } \\
\text { les (in euros) } \\
\text { in euros). } \\
\text { Ider Equity R } \\
\text { Assets (Earr } \\
\text { at the } 1 \%, \\
\text { hitney test). }\end{array}$ & $\begin{array}{l}\text { otal Sharehol } \\
\text { efore interes } \\
\text { ficant at the }\end{array}$ & $\begin{array}{l}\text { quity/Total As } \\
\text { taxes/Total A } \\
\text { significant at }\end{array}$ & $\begin{array}{l}\text { is) } \\
\text { 10\% level. Th }\end{array}$ & once in & tected \\
\hline
\end{tabular}

A word of caution is warranted here. In effect, the statistics pertaining to the new restaurants must be read with caution since most of these firms are not incorporated right at the beginning of 2012 As such, the accounting data available for many of them is not for a full calendar year. With this in mind, it is still interesting to see that the new restaurants in the sample are small (median total assets $=€ 30.0$ thousand; median sales $=€ 34.9$ thousand), and unable to generate positive cash-flow (median cash-flow $=-€ 11.1$ thousand). Industry rivals are considerably bigger (median total assets $=€ 105.5$ thousand; median sales $=€ 150.1$ thousand), but are also not generating positive cash-flow (median cash-flow = $€ 7.4$ thousand). Importantly, the $t$ - and Wilcoxon-Mann-Whitney tests for total assets, sales, and cash-flow are statistically significant normal levels, suggesting that the new restaurants, and their respective industry rivals are fundamentally different.

Table 2 also shows that, in 2012, the sample firms have a very unbalanced capital structure, a situation that seems particularly acute for the new restaurants this paper considers. In fact, for these firms, the mean (median) shareholder equity ratio is $-46.8 \%$ $(-16.6 \%)$. The corresponding figure for the industry rivals is $-61.7 \%$ (8.5\%). Now the $t$-test for differences in means is not significant but its counterpart Wilcoxon-Mann-Whitney test is at the $5 \%$ level. Finally, Table 2 shows that the new restaurants and their industry rivals are clearly unprofitable. In particular, the mean return-onassets for the former is $-76.8 \%$ and is $-34.2 \%$ for the latter. Median results are better but still very negative: $-35.4 \%$, and $-12.2 \%$, respectively. Importantly, both the $t$-test and the Wilcoxon-MannWhitney tests are significant at the $1 \%$ level, which suggests that the difficulties in transforming assets into profits are particularly acute in the case of the new restaurants.

\section{Methodology}

The previous literature exploring intra-industry effects typically employs standard event-study methods that rely on stock returns (e.g. Akhigbe et al., 2003; Hsu et al., 2010; Cotei \& Farhat, 2013).
Yet, since this paper's sample firms are not publicly traded, the alternative event-study method outlined by Barber \& Lyon (1996) is employed. The major advantage of this method is that it uses accounting and not market data to assess to what extent a particular event affects the operating performance of predetermined companies. The next sub-sections detail how the Barber \& Lyon's (1996) method is used in the present research.

\subsection{Event, event-firms and event-period}

An event-study requires a well-defined event, which, in this paper, is the birth of a new restaurant in one of the 308 Portuguese municipalities in 2012. One also needs to be clear on who the event-firms are. These are the companies that are likely to be affected by the event of interest. Hence, in this paper, industry rivals are the event-firms as our main purpose is to explore to what extent the birth of a new restaurant affects their operating performance. Implementing an event-study also requires defining an event-period. In this study, 2012 is the event-year (denoted as year $t$ hereafter) since this is when the new restaurants open for business. Furthermore, this paper considers the year preceding the event-year (i.e. year $t$-1), as well as its subsequent year (i.e. year $t+1)$.

\subsection{Abnormal performance metric}

The early literature employs earnings-based metrics as proxies for the firms' operating performance (e.g. Healy \& Palepu, 1988 and 1990; Asquith, Healy \& Palepu, 1989). Yet, Barber \& Lyon (1996) favor using operating income since earnings figures can be clouded by special items, tax considerations or the accounting for minority interests. Hence, drawing on Barber \& Lyon (1996), return-onassets (ROA) is used has the main operating performance metric. This is a widely used profitability measure, which shows to what extent management is able to employ the firm's assets to generate operating profits. Furthermore, ROA is also particularly relevant when comparing the performance of competing companies within the same industry. In this paper, ROA is computed as the ratio of 
earnings before interest and taxes (EBIT) to the average of beginning- and ending-period year book value of total assets. This paper considers two auxiliary performance metrics drawn from the DuPont System of Analysis, which shows how to break ROA into its basic components. The first is the firm's profit margin (PM), computed as the ratio of EBIT to sales. This ratio expresses the profit generated per unit of sales, and has the advantage of being immune to problems of 'historic cost'. The second is the asset turnover ratio (ATURN), computed as the ratio of sales to the average of beginning- and ending-period year book value of total assets. ATURN helps understand how efficiently firms are at deploying their assets to generate sales.

\subsection{Models of expected operating performance}

One of the most challenging aspects of an event-study is specifying the predicted performance of the event-firms in the absence of the event of interest. The basic idea is to compare the event-firms' performance with that of benchmark firms sharing similar levels of risk but that do not experience the event. Barber \& Lyon (1996) examine different models of the expected operating performance, and conclude that the only model that yields well-specified test statistics in all situations they consider is a change model where benchmark firms are matched on size and pre-event performance. This paper follows the same approach. In particular, the expected performance of industry rival $i$ in year $t+l$ using year $t$ as the base year is given by:

$$
E\left(P_{i, t+l}\right)=P_{i, t}+\left(P I_{i, t+l}-P I_{i, t}\right)
$$

where, $P_{i, t}$ is the actual performance of industry rival $i$ in year $t$ and $P I_{i, t}$ is the performance of the respective benchmark group in year t.

Following Barber and Lyon (1996), benchmark firms are matched on size and pre-event performance, in that order. For each industry rival $i$, this paper identifies all Portuguese firms in the AMADEUS database that have a book value of assets in year $t-2$ that lies between $70 \%$ and $130 \%$ of that of the industry rival firm's book value of assets in the same year. Match candidates that do not have a ROA that lies in the $90 \%$ to $110 \%$ interval of the ROA of its corresponding industry rival $i$ are excluded. Next, all candidates that do not have enough data to conduct our study over the eventperiod of interest are also removed as Barber \& Lyon (1996, p. 377) recommend holding the benchmark group of firms constant over time. Finally, following Barber \& Lyon (1996, p. 369), this paper uses the median of the benchmark group as proxy for the performance of the control group in each year in the event-period.

\subsection{Statistical significance of the abnormal performance}

Once the model of expected performance is specified as above, one can compute the abnormal performance of rival firm $i$ in year $t+l$ using year $t$ as the base year as follows:

$$
A P_{i, t+l}=P_{i, t+l}-E\left(P_{i, t+l}\right)
$$

where $P_{i, t+l}$ is the actual performance of the rival firm $i$ in year $t+l$ and $E\left(P_{i, t+l}\right)$ is given by Equation (1).

This paper reports results for the average abnormal performance of the rivals when a given new restaurant has more than one competitor in the sample. Such procedure ensures that every event (i.e. the birth of a new restaurant) has the same weight in the results.

In the final step, one needs to test whether the abnormal performance computed as per Equation (2) is significantly different from zero. Following Barber \& Lyon (1996), the Wilcoxon signed-rank test is employed for this purpose. Yet, unfortunately, the skewness of the distribution affects the results of such test (Conover, 1999). In order to account for this problem, this paper also results using the less powerful sign test. Further, for completeness, parallel results using parametric $t$-tests are also reported.

\section{Results}

Table 3 summarizes this paper's main results. The first row shows the abnormal operating performance of the industry rivals in the year their new competitors open for business. In particular, the rivals' ROA in 2012 is compared with that of 2011, adjusting for risk using the benchmark firms matched on size and ROA. As can be seen, the median (mean) abnormal performance of the industry rivals is $-12.3 \%(-17.6 \%)$, statistically significant at better than the $1 \%(1 \%)$ level. To help interpret this result, suppose that in Equation (1) $P I_{i, 2012}-P I_{i, 2011}$ is zero for all the benchmark firms we consider (i.e. assume a zero variation in ROA for these firms). If this were the case, Equation (1) suggests that the rivals' ROA in 2012 is similar to that in 2011. The evidence portrayed in the first row of Table 3, however, suggests otherwise, namely that the ROA of the "typical" industry rival is much larger in 2011 than in 2012. In other words, the evidence in Table 3 suggests that industry rivals underperform in risk-adjusted terms in the year their new competitors start operating in the market.

Table 3 - Industry rivals' abnormal performance using ROA, matching on size and pre-event performance

\begin{tabular}{|c|c|c|c|c|c|c|c|}
\hline Initial Year & Final Year & AP Mean & AP Median & T-test (p-Value) & WSR test (p-value) & Sign test (p-value) & Skewness \\
\hline 2011 & 2012 & $-17.6 \%$ & $-12.3 \%$ & 0.00 & 0.00 & 0.00 & -0.4 \\
\hline 2012 & 2013 & $-0.9 \%$ & $1.0 \%$ & 0.86 & 0.19 & 0.21 & -3.7 \\
\hline
\end{tabular}

The second row of Table 3 summarizes what happens in the year following the event of interest. To be specific, the ROA of the industry rivals in 2013 is compared with that of 2012, and results are again adjusted for risk using the benchmark firms matched on 
size and ROA. As can be seen, the $t$-, Wilcoxon signed-rank, and sign tests are not significant even at the $10 \%$ level. Therefore, now the evidence suggests that, in the year following the birth of the new restaurants, industry rivals exhibit an operating performance that is consistent with that one could reasonably expect in the absence of such an event.

Table 4 sheds further light on this paper's main results. In particular, it shows what happens when the additional PM and ATURN metrics are used as performance measures in the eventstudy. In the first row of Panel A of Table 4, this paper compares the PM of the rivals in 2012 with that of 2011, adjusting for risk using benchmark firms matched on size and ROA. As can be seen, industry rivals now exhibit a median (mean) abnormal performance of $-7.8 \%(-11.6 \%)$, which is significant at better than the $1 \%(1 \%)$ level. Moreover, when one considers the subsequent year to the event of interest in the second row of Panel A of Table 4 , we find that both of the parametric and non-parametric tests are not significant at even the $10 \%$ level. It follows that the results for PM mimic what is found when ROA is employed as the performance metric. To be specific, Panel A of Table 4 reveals that the birth of a new restaurant severely and negatively impacts the profit margin of its competitors in the year it opens for business. Yet, 12 months later, rival firms seem to have learnt how to deal with this event, displaying an ability to generate operating profits from sales that is consistent with that of similar, non-event firms.

Table 4 - Industry rivals' abnormal performance using PM and ATURN, matching on size and pre-event performance

\begin{tabular}{|c|c|c|c|c|c|c|c|}
\hline Initial Year & Final Year & AP Mean & AP Median & T-test (p-Value) & WSR test ( $p$-value) & Sign test ( $p$-value) & Skewness \\
\hline \multicolumn{8}{|c|}{ Panel A: operating performance is measured by PM } \\
\hline 2011 & 2012 & $-11.6 \%$ & $-7.8 \%$ & 0.00 & 0.00 & 0.00 & -1.8 \\
\hline 2012 & 2013 & $2.1 \%$ & $0.6 \%$ & 0.30 & 0.18 & 0.29 & 0.1 \\
\hline \multicolumn{8}{|c|}{ Panel B: operating performance is measured by ATURN } \\
\hline 2011 & 2012 & $-4.9 \%$ & $-9.0 \%$ & 0.04 & 0.02 & 0.04 & 3.0 \\
\hline 2012 & 2013 & $22.4 \%$ & $6.7 \%$ & 0.00 & 0.01 & 0.03 & 2.0 \\
\hline
\end{tabular}

Panel B of Table 4 summarizes the results when ATURN is the performance metric. Consistent with the evidence reported for ROA and PM, this paper finds that the median abnormal operating performance of the industry rivals is negative $(-9.0 \%)$ and statistically significant (at the $5 \%$ level) in the year of the birth of the new restaurants in the sample. Parametric results tell a similar story: the mean abnormal performance of the industry rivals is $-4.9 \%$, significant at the $5 \%$ level. Interestingly, results for the subsequent year are, however, very different. In effect, as can be seen in the second row of Panel B of Table 4, industry rivals now seem to overperform relative to their size and ROA benchmark firms. In particular, their median abnormal operating performance for such event-period is $+6.7 \%$ (significant at normal levels using both the Wilcoxon signed-rank and the sign test), and the corresponding mean is $+22.4 \%$ (the $p$-value of the $t$-test is less than $1 \%$ ). Together, these results show that the birth of a restaurant seems to harm its industry rivals' ability to transform assets into sales in the year these new competitors start doing business. Yet, the "typical" rival soon seems to realize how to deal with this effect, since it displays a higher capacity to generate sales per unit of assets in the following year relative to similar firms that do not face the additional competition.
Overall, the evidence discussed in the previous paragraphs suggests that new restaurants significantly affect the operating performance of their respective industry rivals. In particular, preexisting firms underperform relative to size and ROA benchmark firms in the ability to use assets to generate operating profits, a phenomenon that seems to be due to an abnormal loss in profit margin and asset turnover ratio. This, however, is a short-term effect. In fact, in the subsequent year, industry rivals exhibit a level of operating performance as measured by ROA that is statistically similar to what one could expect if no new restaurant had opened for business. What is more, in that year, industry rivals enjoy an adequate profit margin relative to their risk, and seem to outperform similar non-event firms in their ability to transform assets into sales.

\section{Regression analysis}

In this section, regression analysis is used to shed some light on the factors that explain why the birth of a new restaurant affects the operating performance of its industry rivals. The following regression model is considered:

$$
\begin{aligned}
& A P_{j}=\alpha_{0}+\lambda_{1} H H_{j}+\lambda_{2} \text { WEIGHT }_{j}+\lambda_{3} \text { RROA }_{j}+\lambda_{4} \text { SALES }_{-} \text {EMP }_{j}+\lambda_{5} \text { COST_EMP } \\
& +\lambda_{6} \text { Big }_{-} \text {City }_{j}+\varepsilon_{j}
\end{aligned}
$$

(4) where $A P_{j}$ is the abnormal performance of the industry rivals of a given new restaurant $j$, the independent variables are for five industry characteristics and one control variable, and $\varepsilon_{j}$ is the error term, assumed to be white noise. Given the event-study results presented above, the dependent variable is the rivals' abnormal performance in the year the new restaurants open for business when ROA is the performance metric.
The first independent variable is industry concentration ( $\mathrm{HH})$. To help understand why this variable should be important consider a situation where, in a given city, only one restaurant exists. If this is the case, the city's market is fully concentrated: this economic unit is a monopoly. Now assume that a new restaurant starts working in the same city. This increases competition (i.e. industry concentration decreases), which is likely to negatively affect the operating performance of the pre-existing restaurant. This 
explains why one should expect that the birth of a new restaurant penalizes more its respective rivals when industry concentration in the city is high. Drawing on the previous literature exploring the intra-industry effects triggered by different events (e.g. Lang \& Stulz, 1992, Jorion \& Zhong 2010 and Zhang, 2010), this paper uses the Herfindahl ratio to calculate the degree of industry concentration. Such index is computed with data collected at the 2010 year-end as the squared sum of the fractions of the restaurant sales (i.e. higher values mean more concentrated industries) by all non-event restaurants located in the same city.

The second independent variable considered in the regression model is the rivals' direct market share. To motivate its use, consider a situation where only three restaurants exist in a given city. Restaurant $A$ is in the city center while restaurants $B$ and $C$ are located at the city's industrial park. Assume further that the city center is several miles away from the industrial park, and that restaurant $A$ is responsible for $95 \%$ of the sales of the eating-places industry in the city. Under this setup, industry concentration in the city is high but, clearly, opening a new restaurant at the city centre or at the city's industrial park should have a different impact on the operating performance of the pre-existing businesses. In fact, as with industry concentration, one should expect that the additional competition will affect more negatively the performance of the rivals when they command a larger market share of the city's restaurant business. WEIGHT is then used to control for this characteristic, and is computed as the ratio of the total sales of the industry rivals of new restaurant $j$ in 2010 to the total sales of the restaurants in the same city in that year.

Profitability is another important aspect that one should consider when exploring the effects of the birth of a new restaurant on the operating performance of its industry rivals. In effect, profitable pre-existing rivals are likely to be less affected by the added competition than similar firms that are already struggling before the new player opens for business. To explore this issue, this paper considers RROA in the regression model above. This independent variable measures the profitability of the industry rivals before the birth of their new competitor, and is computed as the ratio of their EBIT in 2010 to their average of the book value of total assets in 2009 and 2010.

This paper also explores to what extent the relation between profitability, the birth of a new restaurant and the impact of such event on the rivals' operating performance is contingent on whether the rivals outperform their industry peers or not. To see why this is an important aspect, consider the case of new restaurants $A$ and $B$, which are located in two different cities. Before restaurant $A(B)$ opened for business, its sole competitor had a ROA of $4 \%(-5 \%)$. Now consider that, on average, the eatingplaces industry in the city of restaurant A (B) generated a ROA of $10 \%(-7 \%)$. Under this set up, the rival of restaurant $A$ is more profitable than the rival of restaurant $B$ in absolute terms ( $4 \%$ vs. $5 \%$ ); yet it is underperforming relative to its industry peers ( $4 \%$ vs. $10 \%)$. The converse situation applies to restaurant B (-5\% vs. $-7 \%)$. This simple example shows that although RROA is useful for capturing the absolute differences in profitability, it does not consider that rivals may actually be under or outperforming their respective industry peers. This paper deals with this issue by including the dummy variable D_BETTER in the regression model

above. D_BETTER equals one when the rivals of the new restaurant j outperform their city's industry peers ROAwise.

The eating-places industry is very labor-intensive. For instance, on average, in 2010, the Portuguese restaurants present in the AMADEUS database paid out 44.6 cents in labor cost per euro of sales. Accordingly, it is important to study the role that labor productivity plays in this paper's initial findings. This is done with the help of two independent variables. The first, SALES_EMP, accounts for the productivity of the employees working for the rivals relative to the productivity of the employees working in the other restaurants in the same city. SALES_EMP is computed as follows. First, for each new restaurant j, rivals' labor productivity is given by the ratio of sales to total number of employees in 2010. Second, the average of the same ratio is computed for the other restaurants operating in the same city and year. In the last step, this paper divides the labor productivity of the rivals by the labor productivity of the industry peers, and uses this figure in the regression model. When SALES_EMP is (more than) one, than the labor productivity of the rivals equals (is higher than) that of their city's peers. COST_EMP is the second labor-related variable included in the estimation of Equation (4). It is also a productivity measure, which now focuses on the costs of labor. In effect, COST_EMP and SALES_EMP are computed similarly: the difference is that the former uses the cost per employee instead of sales per employee. If follows that when COST_EMP is (less than) one, than the rivals' cost of labor equals (is lower than) that of their city's peers.

Table 1 shows that a third of the new restaurants in the sample are incorporated in Lisbon or Oporto. As such, it is important to control for a possible "location effect" in the regression results. The dummy variable BIG_CITY is used to that end, which assumes the unit value when the new restaurant is incorporated in one of these two cities (and, thus, its rivals operate in such cities), and zero otherwise.

Table 5 reports descriptive statistics for the continuous independent variables included in the regression model. All variables are winsorized at the $1 \%$ and $99 \%$ level to abstract from the influence of extreme outliers. As can be seen, the restaurant industry in the cities this paper considers does not seem to be particularly concentrated (mean $\mathrm{HH}=0.06$; median $\mathrm{HH}=0.02$ ) nor do the rivals in the sample command a large market share (mean WEIGHT $=3.3 \%$, median WEIGHT $=0.6 \%$ ). In addition, the typical industry rival is unprofitable before the birth of its new competitor. The mean return-on-assets is $-8.7 \%$, with a corresponding median of $0.2 \%$. Yet, the standard deviation of RROA is large $(25.4 \%)$ as is the range between the minimum and maximum value for such variable $(-71 \%$ and $35.2 \%$, respectively). Finally, Table 5 suggests that the rivals in the sample and their city's industry peers have similar productivity levels. In particular, the mean SALES_EMP (COST_EMP) is 1.02 (1.01), and the corresponding median is $0.96(0.97)$.

\section{Table 5 - Descriptive statistics for the continuous independent} variables included in the regression model

\begin{tabular}{|l|c|c|c|c|c|}
\hline \multicolumn{1}{|c|}{ Variable } & Mean & StdDev & Min & Median & Max \\
\hline HH & 0.06 & 0.08 & 0.01 & 0.02 & 0.44 \\
\hline WEIGHT & $3.3 \%$ & $6.1 \%$ & $0.0 \%$ & $0.6 \%$ & $26.1 \%$ \\
\hline RROA & $-8.7 \%$ & $25.4 \%$ & $-71.0 \%$ & $0.2 \%$ & $35.2 \%$ \\
\hline SALES_EMP & 1.02 & 0.41 & 0.36 & 0.96 & 2.42 \\
\hline COST_EMP & 1.01 & 0.25 & 0.51 & 0.97 & 1.70 \\
\hline \multicolumn{3}{|c}{ Source: Own elaboration. } \\
\hline
\end{tabular}


Table 6 presents Pearson correlation coefficients for the same independent variables. As can be seen, the largest estimated coefficient is $0.39(p<0.01)$ for SALES_EMP and COST_EMP, followed by that between RROA and SALES_EMP $(0.38, p<0.01)$. Although significant, these coefficients are not particularly high. Importantly, many of the correlations are not significant at normal levels. Together, the evidence in Table 6 suggests that the independent variables considered in Equation (4) seem to proxy for different underlying factors.

Table 6 - Pearson correlation coefficients for the continuous independent variables included in the regression model

\begin{tabular}{|c|c|c|c|c|}
\hline VARIABLE & $\mathrm{HH}$ & WEIGHT & RROA & SALES_EMP \\
\hline WEIGHT & 0.17 & & & \\
\hline (P-value) & 0.01 & & & \\
\hline RROA & 0.08 & 0.20 & & \\
\hline (P-value) & 0.27 & 0.03 & & \\
\hline SALES_EMP & 0.03 & 0.34 & 0.38 & \\
\hline (P-value) & 0.70 & $<0.01$ & $<0.01$ & \\
\hline COST_EMP & 0.05 & 0.31 & 0.24 & 0.39 \\
\hline (P -value) & 0.51 & $<0.01$ & 0.05 & $<0.01$ \\
\hline
\end{tabular}

Table 7 summarizes the results of estimating Equation (4). A Reset test is employed to exclude problems of incorrectly omitted variables and/or incorrect functional form, together with a White test for heteroscedasticity. As can be seen, the Reset test is not significant but the White test is at better than the $1 \%$ level. As a result, Equation (4) is estimated using ordinary least squares (OLS), and standard errors are corrected as suggested by White (1980). Importantly, Table 7 shows that the model's R-Squared is $22.9 \%$, which suggests that the independent variables jointly explain around one fifth of the variability of the rivals' abnormal operating performance.

Table 7 - Regression results, using size and pre-event benchmark firms to compute rivals' abnormal performance

\begin{tabular}{|l|l|l|}
\hline INDEPENDENT VARIABLE & Estimate & P-value \\
\hline INTERCEPT & -0.03 & 0.78 \\
\hline HH & -0.44 & 0.08 \\
\hline WEIGHT & -0.20 & 0.34 \\
\hline RROA & 0.32 & $<0.01$ \\
\hline D_BETTER & 0.28 & $<0.01$ \\
\hline SALES_EMP & 0.06 & 0.37 \\
\hline COST_EMP & -0.25 & 0.01 \\
\hline BIG_CITY & -0.12 & 0.01 \\
\hline N & 108 & \\
\hline Reset (F-Stat. Sig.) & 0.34 & \\
\hline White (F-Stat. Sig.) & $<0.01$ & \\
\hline R-Squared & $22.9 \%$ & \\
\hline Adjusted R-Squared & $20.3 \%$ & \\
\hline Notes: 1. N: number of observations / 2. RESET: $p$-value of the Reset test / 3. White: $p$-value of the
\end{tabular}

Notes: 1. N: number of observations / 2. RESET: $p$-value of the Reset test / 3. White: $p$-value of the Reset test

This paper now moves on to discuss the individual impact of the different independent variables. For instance, Table 7 shows that the estimated coefficient for $\mathrm{HH}$ is negative and statistically significant at normal levels. Hence, in line with this paper's initial expectations, there is evidence that, ceteris paribus, an increase in the city's eating-places industry concentration magnifies the negative impact of the birth of a new competitor on the abnormal operating performance of its industry rivals. Table 7 also shows that the estimated coefficient for both RROA and D_BETTER are positive and statistically significant at better than the $1 \%$ level. Recall that the first variable measures the profitability of the rivals' assets in anticipation to the birth of the new restaurants, while the second is a dummy variable that assumes the unit value when the industry rivals outperform their city competitors in their ability to transform assets into profits. As such, Table 7 shows that, all else being equal, pre-existing rivals that are more profitable cope better with the birth of a new competitor, a phenomenon that is magnified when they are better at using assets to generate operating profits than their city's peers.

There is also evidence that labor productivity plays an important role in explaining the cross-section variability of the dependent variable. In fact, the coefficient estimated for COST_EMP is negative and statistically significant. As explained above, higher values for this variable indicate that the rivals sustain a higher cost per employee than their city peers. Hence, Table 7 suggests that, ceteris paribus, relative lower labor productivity leads rivals to exhibit more negative abnormal performance once a new restaurant enters the market. Table 7 also shows that the estimated coefficient for BIG_CITY is negative and significant at the $5 \%$ level. Recall that this is dummy variable is one when the new restaurant is incorporated at Lisbon or Oporto. As such, the evidence now reported suggests that a "location effect" exists: ceteris paribus, rivals based at these two cities are more affected by the opening for business of a new competitor than similar restaurants located elsewhere at Portugal.

Finally, it is worth mentioning that the estimated coefficients for WEIGHT and SALES_EMP are not statically significant even at the $10 \%$ level. This suggests that, once the remaining factors are accounted for, these two variables have no incrementally power to explain the industry rivals' abnormal performance.

\section{Conclusion}

How does the birth of a new restaurant affect the operating performance of its industry rivals? This paper sheds light on this issue with the help of a sample of 108 new restaurants that were incorporated in one of the 308 Portuguese municipalities in 2012, and their respective industry rivals. Using event-study methods, this paper finds that, in the year the new competitors open for business, on average, industry rivals underperform by $-17.6 \%$ in ROA a set of benchmark firms matched on size and pre-event performance. When breaking down ROA into its two basic components, this paper finds that such underperformance is due to an abnormal loss in the rivals' profit margin and asset turnover ratio. The event-study results, however, suggest that this is a shortterm effect. In particular, in the subsequent year to the birth of the new restaurants, their respective industry rivals' operating performance matches what one could expect given their level of risk.

The second part of the paper uses regression analysis to investigate what drives the rivals' initial underperformance. Results show that, ceteris paribus, such an effect is stronger for restaurant based at Lisbon and Oporto, which are the two biggest Portuguese cities. Furthermore, industry characteristics such as concentration and labor productivity also magnify the rivals' underperformance. On the other hand, the regression results show that profitable pre-existing restaurants are less likely to experience negative abnormal operating performance when their new competitors open for business. 
This paper makes an important contribution to the literature as it is the first to explore the intra-industry effects resulting from the birth of a new restaurant. To the best of the author's knowledge, no previous study has addressed this important issue, since the somewhat related literature focuses on the impact of IPOs on their listed competitors, not addressing the eating-places industry in particular. In addition, this paper's results should also inform practice. In particular, investors and managers working in the eating-places industry should worry with each new restaurant that opens for business as such added competition seems to lead to an abnormal loss of profitability of the pre-existing firms. This is particularly relevant for restaurants in the largest cities, in cities with high industry concentration, and for companies with low labor productivity, and profitability. The findings of this research also have significant public policy implications. In effect, they stress that regulators must strive to design a set of rules for the eating-places industry that limits the possibility for an unrestrained competition in the sector, which would eventually question its future economic sustainability.

Like most studies, the present research has several limitations, and its findings must be interpreted with caution. For instance, this paper's conclusions and implications are drawn from a sample of 108 new Portuguese restaurants incorporated in 2012, and their respective 157 industry rivals. This is clearly a particular setting to explore this paper's main research question since the significant deterioration of the fiscal situation at Portugal resulted in an intervention by the International Monetary Fund, the European Union, and the European Central Bank in the spring of 2011. Although the event-study methodology employed in this paper explicitly accounts for this issue, since both the rival firms and their respective benchmark firms experienced identical market conditions, further research could help understand to what extent this paper's findings hold in different macroeconomic settings. Similarly, further research could test the robustness of this paper's findings by exploring a similar issues using data from other countries and covering a different time period.

\section{Acknowledgements}

This paper has benefited from the comments, inter alia, of Rúben Peixinho, Siri Terjensen, and participants in Research Seminars at the School of Economics - University of the Algarve and Universidad Pablo de Olavide. The author acknowledges partial financial support from the School of Economics - University of the Algarve. The author is pleased to acknowledge financial support from Fundação para a Ciência e a Tecnologia (grant UID/ECO/04007/2013) and FEDER/COMPETE (POCI-010145-FEDER-007659).

\section{References}

Agut, S., Grau, R., \& Peiró, J. (2003). Competency needs among managers from Spanish hotels and restaurants and their training demands. International Journal of Hospitality Management, 22(3), 281-295.

Akhigbe, A., Borde, S., \& Whyte, A. (2003). Does an industry effect exist for Initial Public Offerings? The Financial Review, 38(4), 531-551.

Akhigbe, A., Madura, J, \& Martin, A. (2015). Intra-industry effects of negative stock price surprises. Review of Quantitative Finance \& Accounting, 45(3), 541-559.

Asquith, P., Healy, P., \& Palepu, K. (1989). Earnings and stock splits. The Accounting Review, 64(3), 387-403.

Asthana, S., \& Mishra, B. (2001). The differential information hypothesis, firm size, and earnings information transfer: an empirical investigation. Journal of Business Research, 53(1), 37-47.
Barber, B., \& Lyon, J. (1996). Detecting abnormal operating performance: the empirical power and specification of test statistics. Journal of Financial Economics, 41(3), 359-399.

Braun, M., \& Larrain, B. (2009). Do IPOs affect the prices of other stocks? Evidence from Emerging Markets. The Review of Financial Studies, 22(4), 1505-1544.

Central Bank of Portugal (2011). Análise Sectorial do Alojamento, Restauração e Similares. Retrieved April, 07, 2016 from https://www.bportugal.pt/pt-

PT/ServicosaoPublico/CentraldeBalancos/Biblioteca\%20de\%20Tumbnails /Estudos\%20da\%20CB\%205_2011.pdf

Chang, J., Hung, M. \& Tsai, F. (2015). Credit contagion and competitive effects of bond rating downgrades along the supply chain. Finance Research Letters, 15 (November), 232-238.

Conover, W. (1999). Practical Nonparametric Statistics (3rd Edition). New York: Wiley.

Cotei, C., \& Farhat, J. (2013). Informational externalities of initial public offerings: Does venture capital backing matter? Journal of Economics and Finance, 37(1), 80-99.

EU Centre in Singapore (2013). Tourism as a driver of economic growth and development in the EU- 27 and ASEAN regions. Retrieved April, 07, 2016 from http://www.eucentre.sg/wp content/uploads/2013/12/EUCResearchBrief_TourismEU27ASEAN.pdf

European Commission (2014). Annual Report on European SMEs 2013/2014 - A Partial and Fragile Recovery. Retrieved April, 07, 2016 from http://ec.europa.eu/growth/smes/business-friendlyenvironment/performance-review/files/supportingdocuments/2014/annual-report-smes-2014_en.pdf

Firth, M. (1996). Dividend changes, abnormal returns, and intra-industry firm valuations. Journal of Financial and Quantitative Analysis, 31(2), 189-211.

Foster, G., Olsen, C., \& Shevlin, T. (1984). Earnings releases, anomalies and the behavior of security returns. Accounting Review, 59(4), 574-603.

Gleason, C., Jenkins, N., \& Johnson, W. (2008). The Contagion Effects of Accounting Restatements. The Accounting Review, 83(1), 83-110.

Healy, P., \& Palepu, K. (1990). Earnings and risk changes surrounding primary stock offers. Journal of Accounting Research, 28(1), 25-48.

Healy, P., \& Palepu, K. (1988). Earnings information conveyed by dividend initiations and omissions. Journal of Financial Economics, 21(2), 149-176.

Hsu, H., Reed, A., \& Rocholl, J. (2010). The New Game in Town: Competitive Effects of IPOs. Journal of Finance, 65(2), 495-528.

Jorion, P., \& Zhang, G. (2010). Information transfer effects of bond rating downgrades. Financial Review, 45(3), 683-706.

Kim, S., \& Upneja, A. (2014). Predicting restaurant financial distress using decision tree and AdaBoosted decision tree models. Economic Modelling, 36, 354-362.

Koys, D., \& DeCotiis, T. (2015). Does a good workforce influence restaurant performance or does good restaurant performance influence the workforce? Journal of Human Resources in Hospitality \& Tourism, 14(4), 339-356.

Lang, L., \& Stulz, R. (1992). Contagion and competitive intra-industry effects of bankruptcy announcements: an empirical analysis. Journal of Financial Economics, 32(1), 45-60.

Lu, J., \& Beamish, P. (2001). The internationalization and performance of SMEs. Strategic Management Journal, 22(6-7), 565-586.

Mayer-Haug, K., Read, S., Brinckmann, J., Dew, N., \& Grichnik, D. (2013). Entrepreneurial talent and venture performance: $A$ meta-analytic investigation of SMEs. Research Policy, 42(6-7), 1251-1273.

Murphy, K. (2007). A proposed framework for measuring human capital intangible value component in restaurant organizations using Economic Value Added. Journal of Foodservice Business Research, 10(3), 3-23.

Pyo, Y., \& Lustgarten, S. (1990). Differential intra-industry information transfer associated with management earnings forecasts. Journal of Accounting and Economics, 13(4), 365-379.

Ramnath, S. (2002). Investor and analyst reactions to earnings announcements of related firms: An empirical analysis. Journal of Accounting Research, 40(5), 1351-1376.

Simpson, M., Padmore, J., \& Newman, N. (2012). Towards a new model of success and performance in SMEs. International Journal of Entrepreneurial Behavior \& Research, 18(3), 264-285. 
Statistics Portugal (2012). Estatísticas do Turismo. Retrieved April, 07, 2016

from

https://www.ine.pt/xportal/xmain?xpid=INE\&xpgid=ine_publicacoes

Szewczyk, S. (1992). The intra-industry transfer of information inferred from announcements of corporate security offerings. Journal of Finance, 47(5), 1935-1945.

Tawatnuntachai, O., \& D'Mello, R. (2002). Intra-Industry Reactions to Stock Split Announcements. Journal of Financial Research, 25(1), 39-57.

Thanh, N., Ninon, S. \& Dung, P. (2014). Intra-Industry Effects of IPOs on Stock Repurchase Decisions of Rival Firms. Journal of Accounting \& Finance, 14(4), 61-82.

Thomas, J., \& Zhang, F. (2008). Overreaction to Intra-industry Information Transfers? Journal of Accounting Research, 46(4), 909-940.

Tookes, H. (2008). Information, trading, and product market interactions: Cross-sectional implications of informed trading. Journal of Finance, 63(1), 379-413.

White, H. (1980). A heteroskedasticity-consistent covariances matrix estimator and a direct test for heteroskedasticity. Econometrica, 48(4), 817-838.

Xin, Y., Peng, Z. \& Ying, Z. (2015). Corporate Governance, Political Connections, and Intra-Industry Effects: Evidence from Corporate Scandals in China. Financial Management, 44(1), 49-80.

Zhang, G. (2010). Emerging from Chapter 11 bankruptcy: Is it good news or bad news for industry competitors? Financial Management, 39(4), 17191742.

Received: 30 April 2016

Revisions required: 25 September 2016

Accepted: 5 January 2017 